\title{
LIMBAH KULIT PISANG KEPOK (Musa acuminate) SEBAGAI BIOFILTER ZAT BESI (Fe) DAN ZAT KAPUR $\left(\mathrm{CaCO}_{3}\right)$
}

\author{
Skin Waste Of Kepok Banana (Musa Acuminate) As A Biofilter \\ Of Iron ( $\mathrm{Fe}$ ) And Calcium ( $\mathrm{CaCO}_{3}$ ) \\ Budiman $^{1}$, Hamidah ${ }^{2}$, Hasria ${ }^{3}$ \\ 1,3 Department Of Environmental Health Public Health, Muhammadiyah University Palu \\ ${ }^{2}$ Department Of Biostatistics, Population and Familiy Planning Public Health, \\ Muhammadiyah University Palu \\ Email: budimankesling@gmail.com
}

\begin{abstract}
ABSTRAK
Air tanah atau air sumur merupakan sumber air bersih terbesar yang digunakan. Kendala yang paling sering ditemui dalam menggunakan air tanah adalah masalah kandungan zat besi ( $\mathrm{Fe}$ ) dan zat Kapur $\left(\mathrm{CaCO}_{3}\right)$ yang terdapat dalam air baku. Air yang tercemar logam Fe dan zat kapur yang tinggi, bila akan dikonsumsi maka perlu dilakukan pengolahan terlebih dahulu. Pengolahan air untuk menurunkan kadar Fe dan zat kapur dalam air dapat dilakukan secara kimia dan fisika. Proses adsorpsi zat besi (Fe) dan zat kapur $\left(\mathrm{CaCO}_{3}\right)$ dalam air secara alami dapat dilakukan menggunakan tempurung kelapa, arang sekam padi, biji kelor, maupun kulit pisang. Oleh karena itu, penelitian ini bertujuan untuk mengetahui apakah limbah kulit pisang Kepok (Musa acuminate) dapat digunakan sebagai biofilter zat besi dan zat kapur pada air. Penelitian ini menggunakan metode eksperimen yang akan melihat efektifitas perlakuan limbah kulit pisang kepok sebagai biofilter zat besi dan zat kapur pada air bersih. Penelitian ini akan dilakukan di Laboratorium Kesehatan Daerah Provinsi Sulawesi Tengah mulai dari bulan Januari sampai Juli tahun 2018. Hasil penelitian menunjukkan bahwa Limbah kulit pisang Kepok (Musa acuminate) efektif sebagai biofilter zat besi (Fe) dan tidak efektif sebagai biofilter zat kapur $\left(\mathrm{CaCO}_{3}\right)$.
\end{abstract}

Kata Kunci : Zat besi, zat kapur, kulit pisang kepok

\section{ABSTRACT}

Groundwater or well water is the largest source of clean water used. The most common obstacle in using ground water is the problem of iron ( $\mathrm{Fe})$ and Chalk $\left(\mathrm{CaCO}_{3}\right)$ substances found in raw water. Water that is contaminated with Fe and high lime, if it is to be consumed, it needs to be processed first. Water treatment to reduce Fe and lime content in water can be done chemically and physically. The process of natural iron ( $\mathrm{Fe}$ ) and lime $\left(\mathrm{CaCO}_{3}\right)$ adsorption in water can be done using coconut shells, rice husk charcoal, Moringa seeds, and banana peels. Therefore, this study aims to determine whether the waste of banana peel Kepok (Musa acuminate) can be used as an iron and lime biofilter in water. This study uses an experimental method that will see the effectiveness of the treatment of kepok banana peel waste as iron and lime biofilter in clean water. This research will be conducted at the Regional Health Laboratory of Central Sulawesi Province from January to July 2018. The results of the study show that Kepok banana peel (Musa acuminate) is effective as an iron ( $\mathrm{Fe}$ ) biofilter and is not effective as a lime biofilter $\left(\mathrm{CaCO}_{3}\right)$.

Keywords : Iron, calcium, kapok banana skin

\author{
Sekretariat \\ Editorial: Kampus FKM UNISMUH PALU - Palu 94118, \\ Sulawesi Tengah, Indonesia \\ Telp/HP: +6281245936241, Fax (0451) 425627 \\ E-mail: jurnal.mppki@gmail.com \\ OJS: http://jurnal.unismuhpalu.ac.id/index.php/PJKM
}

\author{
Article History: \\ $\Rightarrow \quad$ Received 10 Oktober 2018 \\ $\Rightarrow \quad$ Revised 07 Oktober 2018 \\ $\Rightarrow \quad$ Accepted 24 November 2018 \\ $\Rightarrow \quad$ Available online 31 Desember 2018
}




\section{PENDAHULUAN}

Air bersih di daerah pedesaan dan pinggiran kota digunakan untuk berbagai keperluan. Seperti untuk air minum, memasak, mencuci dan sebagainya yang harus diperhatikan. Cara penjernihan air perlu diketahui karena semakin banyak air yang tercemar limbah rumah tangga maupun limbah industri. Permasalahan ekologis yang menjadi perhatian utama pada saat ini adalah menurunnya kualitas perairan oleh masuknya bahan pencemar yang berasal dari berbagai kegiatan manusia seperti sampah pemukiman, sedimentasi dan siltrasi, industri, pemupukan serta pestisida (Endra, 2013).

Air tanah atau air sumur merupakan sumber air bersih terbesar yang digunakan. Kendala yang paling sering ditemui dalam menggunakan air tanah adalah masalah kandungan zat besi (Fe) dan zat Kapur $\left(\mathrm{CaCO}_{3}\right)$ yang terdapat dalam air baku. Zat besi maupun zat kapur, dalam air biasanya terlarut dalam bentuk senyawa atau garam bikarbonat, garam sulfat, hidroksida dan juga dalam bentuk koloid atau dalam keadaan bergabung dengan senyawa organik (Setiyono, 2014).

Air tanah sering mengandung zat besi (Fe) yang cukup besar. Adanya kandungan Fe dalam air menyebabkan warna air tersebut berubah menjadi kuning-coklat setelah beberapa saat kontak dengan udara. Disamping dapat mengganggu kesehatan juga menimbulkan bau yang tidak enak serta menimbulkan warna kuning pada dinding bak serta bercak-bercak kuning pada pakaian. Oleh karena itu menurut Peraturan Menteri Kesehatan No. 492/MENKES/PER/ IV/2010, kadar zat besi (Fe) dalam air minum maksimum yang dibolehkan adalah 0,3 $\mathrm{mg} / \mathrm{lt}$.

Senyawa besi dalam jumlah kecil didalam tubuh manusia berfungsi sebagai pembentuk sel-sel darah merah, dimana tubuh memerlukan 7-35 mg/hari yang sebagian diperoleh dari air, tetapi zat Fe yang melebihi dosis yang diperlukan oleh tubuh dapat menimbulkan masalah kesehatan. Hal ini dikarenakan tubuh manusia tidak dapat mengsekresi Fe, sehingga bagi mereka yang sering mendapat transfusi darah warna kulitnya menjadi hitam karena akumulasi Fe.
Air minum yang mengandung besi cenderung menimbulkan rasa mual apabila dikonsumsi. Selain itu dalam dosis besar dapat merusak dinding usus. Kematian sering kali disebabkan oleh rusaknya dinding usus ini. Kadar Fe yang lebih dari $1 \mathrm{mg} / \mathrm{l}$ akan menyebabkan terjadinya iritasi pada mata dan kulit. Kelebihan zat besi (Fe) bisa menyebabkan keracunan dimana terjadi muntah, kerusakan usus, penuaan dini, kematian mendadak, mudah marah, radang sendi, cacat lahir, kanker, hepatitis, hipertensi, infeksi, insomnia, sakit liver, masalah mental, rasa logam di mulut, rematik, sikoprenia, sariawan perut, sickle-cell anemia, keras kepala sirosis ginjal, sembelit, diabetes, diare, pusing, mudah lelah, kulit kehitam-hitaman, sakit kepala, gangguan penyerapan vitamin dan mineral, serta hemokromatis (Parulian, 2009).

Selain kandungan zat besi ( $\mathrm{Fe})$ yang tinggi dalam air tanah masyarakat, zat kapur $\left(\mathrm{CaCO}_{3}\right)$ juga merupakan salah satu senyawa yang banyak ditemukan dalam kondisi yang melebihi batas. Menurut Peraturan Menteri Kesehatan RI Nomor 492/Menkes/Per/ IV/2010 tentang persyaratan kualitas air minum kadar maksimum untuk kadar kapur pada air adalah $500 \mathrm{mg} /$ L. Sehingga, diperlukan pengolahan agar air tanah ini dapat memenuhi baku mutu.

Air yang tercemar logam Fe dan zat kapur yang tinggi, bila akan dikonsumsi maka perlu dilakukan pengolahan terlebih dahulu. Pengolahan air untuk menurunkan kadar $\mathrm{Fe}$ dan zat kapur dalam air dapat dilakukan secara kimia dan fisika. Secara kimia, air diolah menggunakan koagulan, seperti: tawas, dan Poly Alumunium Chloride (PAC), sedangkan secara fisika, air diolah dengan proses aerasi, sedimentasi, filtrasi, dan adsorpsi. Proses adsorpsi logam Fe dan zat kapur dalam air secara alami dapat dilakukan menggunakan tempurung kelapa, arang sekam padi, biji kelor, maupun kulit pisang (Mirwan, 2011).

Banyak penelitian yang telah dilakukan untuk menurunkan kadar zat besi dan zat kapur secara alamiah tanpa merusak lingkungan. Misalnya penelitian yang dilakukan oleh Budiman dan Cahya (2015) yang menunjukkan bahwa abu sekam padi pada ketebalan $5 \mathrm{~cm}$ dapat menurunkan zat kapur sebesar $194,16 \mathrm{mg} / \mathrm{l}$ atau $(66,84 \%)$, ketebalan $10 \mathrm{~cm}$ dapat menurunkan zat kapur sebesar 191,57 
$\mathrm{mg} / \mathrm{l}$ atau $(67,28 \%)$ Ketebalan $15 \mathrm{~cm}$ dapat menurunkan zat kapur sebesar 188,65 mg/l atau $67,78 \%$.

Kulit pisang merupakan salah satu alternatif yang dapat digunakan untuk menurunkan kadar zat besi dan zat kapur secara alamiah karena kulit pisang merupakan bahan buangan atau limbah buah pisang yang cukup banyak jumlahnya. Umumnya kulit pisang belum dimanfaatkan secara nyata dan hanya dibuang sebagai limbah organik saja atau digunakan sebagai makanan ternak seperti kambing, sapi dan kerbau. Jumlah dari kulit pisang cukup banyak yaitu sekitar $1 / 3$ dari buah pisang yang belum dikupas. Kulit pisang juga menjadi salah satu limbah dari industri pengolahan pisang, namun bisa dijadikan teknologi dalam penjernihan air (Lubis, 2012).

Menurut Adinata (2013), kulit pisang dapat dijadikan sebagai bahan karbon aktif. Hasil yang didapat untuk nilai karbonisasinya mencapai 96,56\%. Penelitian tersebut hanya diteliti pada proses pembuatan karbon aktif dari kulit pisangnya, tidak sampai kepada aplikasinya ke air.

Berdasarkan penelitian yang dilakukan Nirmala, dkk (2015) menunjukkan bahwa waktu optimum yang diperlukan biocharcoal kulit pisang raja untuk menyerap ion tembaga adalah 60 menit dengan serapannya sebesar 99,64\% sedangkan untuk ion besi adalah 45 menit dengan serapannya sebesar 99,54\%.

Kulit pisang Kepok (Musa acuminate) memiliki kandungan vitamin $\mathrm{C}$, vitamin $\mathrm{B}$, kalsium, protein, selulosa, hemiselulosa, pigmen klorofil, lemak, arabinosa, galaktosa, rhamnosa, dan asam galacturonic. Pisang Kepok dipilih karena pisang ini memiliki kulit yang tebal dibandingkan dengan kulit pisang lainnya, dan pada kulit pisang kepok terkandung senyawa flavonoid yang berpotensi sebagai antioksidan. Berdasarkan hasil penelitian yang dilakukan oleh Castro, dkk (2011) menyebutkan bahwa selulosa dapat mengikat beberapa logam seperti Tembaga $(\mathrm{Cu})$ dan Timbal/Plumbum (Pb).

Kulit dari buah pisang kepok biasanya oleh masyarakat hanya dibuang dan hal itu menjadi permasalahan limbah di alam karena akan meningkatkan keasaman tanah dan mencemarkan lingkungan. Pengenalan penggunaan kulit pisang kepok kepada masyarakat akan lebih efektif bila diterapkan sebagai bahan baku dalam penurunan kadar Fe dan CaCO3.

Hasil observasi awal yang dilakukan di sumber air yang dimanfaatkan oleh masyarakat Kelurahan Talise khususnya di jalan Domba mempunyai ciri-ciri air tanah yang berwarna kuning kecoklatan dan terdapat noda kuning pada bak penampungan air dan pada pakaian. Selain itu, masyarakat juga mengeluh mengalami gatal-gatal pada kulit mereka. Kondisi ini dimungkinkan karena air tersebut memiliki kadar besi yang tinggi. Sedangkan dari hasil pemeriksaan sampel awal zat kapur $\left(\mathrm{CaCO}_{3}\right)$ di Laboratorium Kesehatan Provinsi Sulawesi Tengah, dari 3 sampel yang diteliti yaitu Kelurahan Mamboro sebanyak 182,07 mg/l, Kelurahan Talise sebanyak 585,45 mg/l, Kelurahan Birobuli Selatan sebanyak $333 \mathrm{mg} / \mathrm{l}$ yang berasal dari sumur pompa dan sumur gali, menunjukan bahwa Kelurahan Talise yang memiliki kadungan zat kapur melebihi kadar maksimum yang ditetapkan oleh Peraturan Menteri Kesehatan RI Nomor 492/ Menkes/Per/IV/2010.

Berdasarkan uaraian di atas, maka peneliti tertarik untuk mengkaji mengenai pengaruh biofilter limbah kulit pisang Kepok (Musa acuminate) dalam menurunkan kandungan zat besi (Fe) dan Zat Kapur $\left(\mathrm{CaCO}_{3}\right)$ pada air.

Tujuan penelitian ini adalah untuk mengetahui apakah limbah Kulit Pisang Kepok (Musa acuminate) dapat digunakan sebagai biofilter zat besi (Fe) dalam air

\section{BAHAN DAN METODE}

Jenis penelitian ini adalah eksperimen. Penelitian eksperimen pada dasarnya suatu usaha penyelidikan yang hati-hati dan secara teratur terhadap suatu objek tertentu untuk memperoleh suatu kebenaran atau bukti kebenaran (Notoatmodjo, 2010).

Dalam penelitian ini untuk mengetahui pengaruh variabel bebas (kulit pisang kepok) terhadap variabel terikat (air sumur, kadar besi, kadar kapur).

Sampel air diambil di Jalan Domba Kelurahan Talise Kecamatan Mantikulore Kota Palu dan Pemeriksaan sampel air yang sudah diberi perlakuan dilaksankanan di Laboratorium Kesehatan Daerah Provinsi Sulawesi Tengah. Penelitian ini telah dil- 
aksanakan mulai dari bulan Mei sampai Agustus 2018.

Objek dalam penelitian ini adalah sampel air bersih yang mengandung zat besi dan zat kapur yang diberi perlakuan dengan menggunakan limbah kulit pisang Kepok.

\section{HASIL}

Sampel air dalam penelitian ini diambil dari sumur warga yang tinggal di jalan Domba Kelurahan Talise Kecamatan Mantikulore Kota Palu sebanyak 10 Liter. Hasil pemeriksaan kulit pisang Kepok (Musa acuminate) sebagai biofilter zat besi (Fe) dan zat kapur $\left(\mathrm{CaCO}_{3}\right)$ pada air sumur gali dapat dilihat pada tabel 1 (lampiran).

Dari tabel tersebut menunjukkan bahwa hasil rata-rata tingkat penurunan zat besi setelah diberi penambahan kulit pisang Kepok sebanyak 20 gr yaitu untuk waktu pengamatan 5 menit terjadi penurunan dari $0,05 \mathrm{mg} / \mathrm{L}$ menjadi $0,0167 \mathrm{mg} / \mathrm{L}$. Untuk waktu pengamatan 10 menit terjadi penurunan dari $0,05 \mathrm{mg} / \mathrm{L}$ menjadi 0,0147 $\mathrm{mg} / \mathrm{L}$ dan untuk waktu pengamatan 15 menit terjadi penurunan dari $0,05 \mathrm{mg} / \mathrm{L}$ menjadi $0,0153 \mathrm{mg} / \mathrm{L}$.

Dari tabel 2 (lampiran) mengenai hasil pemeriksaan zat kapur $\left(\mathrm{CaCO}_{3}\right)$ menunjukkan bahwa hasil rata-rata tingkat zat kapur yang diperoleh mengalami peningkatan. Untuk perlakuan waktu 5 menit mengalami kenaikan kadar zat kapur dari 605,13 grL menjadi $700 \mathrm{mg} / \mathrm{L}$; waktu 10 menit juga mengalami kenaikan dari 605,13 mg/L menjadi 706,6 mg/L. Sedangkan untuk waktu 15 menit juga masih mengalami peningkatan kadar zat kapur dari 605,13 mg/L menjadi $695,8 \mathrm{mg} / \mathrm{L}$

\section{PEMBAHASAN}

Pada penelitian ini dilakukan eksperimen sederhana yaitu dengan menambahkan limbah kulit pisang Kepok pada air yang memikili kandungan zat $\mathrm{Fe}$ dan $\mathrm{CaCO}_{3}$ yang melebihi Nilai Ambang Batas (NAB). Setelah dilakukan uji pendahuluan ternyata air sumur tersebut memiliki kandungan ion logam zat besi sebesar $0,05 \mathrm{mg} / \mathrm{L}$ dan zat kapur sebesar 605,13 mg/L. Dari hasil penelitian limbah kulit pisang Kepok sebagai biofilter zat $\mathrm{Fe}$ dan $\mathrm{CaCO}_{3}$ yang telah diperoleh, dapat dijelaskan seperti di bawah ini:

1. Limbah Kulit Pisang Kepok (Musa acuminate) Sebagai Biofilter zat Besi (Fe)

Berdasarkan data yang diperoleh dari hasil penelitian maka diketahui kandungan $\mathrm{Fe}$ pada air sumur sebelum dilakukan perlakuan adalah sebesar $0,05 \mathrm{mg} / \mathrm{L}$, jika dibandingkan setelah perlakuan menggunakan limbah kulit pisang Kepok maka hasil rata-rata yang diperoleh menunjukkan penurunan kandungan zat besi. Dari hasil penelitian juga diketahui bahwa penurunan kandungan zat besi pada waktu kontak 10 menit lebih banyak dibandingkan penuruanan dengan kontak selama 15 menit. Hal ini menunjukkan bahwa waktu efektif yang digunakan untuk menurunkan kandungan zat besi pada air sumur gali dengan menggunakan biofilter limbah kulit pisang Kepok adalah 10 menit.

Selain terjadi penurunan kandungan zat Fe pada air sumur yang disaring, dapat dilihat perbedaan dari segi fisik juga, air yang sebelumnya berbau seperti karat menjadi tidak berbau lagi, karena pada perendaman kulit pisang Kepok dapat menyerap ion Fe dengan efektif. Ditinjau dari struktur kulit pisang Kepok di setiap perendaman yang berbeda dapat mempengaruhi sifat dan muatan elektrostatis dari partikel kulit pisang Kepok. Waktu kontak yang diberikan membuat banyak kesempatan partikel kulit pisang Kepok untuk bersinggungan dengan logam Fe yang terikat di dalam pori-pori kulit pisang Kepok.

Penelitian ini sesuai dengan penelitian yang dilakukan oleh Sitanggang (2010) meskipun dengan menggunakan media yang berbeda yaitu karbon aktif sekam padi yang dapat menurunkan kadar Fe pada air sumur gali sebesar $77,24 \%$.

2. Limbah Kulit Pisang Kepok (Musa acuminate) sebagai Biofilter zat Kapur $\left(\mathrm{CaCO}_{3}\right)$

Berdasarkan data yang diperoleh dari hasil penelitian maka diketahui kandungan CaCO3 pada air sumur sebelum dilakukan perlakuan adalah sebesar $605,13 \mathrm{mg} / \mathrm{L}$, jika dibandingkan setelah perlakuan menggunakan limbah kulit pisang Kepok, hasil rata-rata yang diperoleh menunjukkan adanya peningkatan kandungan zat $\mathrm{CaCO}_{3}$ baik untuk waktu 5 menit, 10 menit maupun 15 menit sehingga dapat ditarik kesimpulan bahwa limbah kulit pisang Kepok tidak efektif sebagai biofilter kandungan zat kapur pada 
air sumur bahkan justru dapat menambah kandungan zat kapurnya.

Kulit pisang kepok tidak cocok untuk digunakan sebagai biofilter zat kapur karena ternyata buah pisang dalam 100 gram daging buahnya mengandung zat kapur sebanyak $358 \mathrm{mg}$. Hal ini menyebabkan kandungan zat kapur yang ada pada air sumur berakumulasi/bertambah dengan zat kapur yang ada pada kulit pisang kepok. Sedangkan bila dibandingkan dengan kandungan zat besi dalam 100 gram daging buah pisang hanya mengandung 0,26 $\mathrm{mg}$ zat besi (Anonim, 2007).

Dari penelitian ini diketahui bahwa untuk menurunkan kandungan zat kapur dibutuhkan media lain seperti penelitian yang dilakukan oleh Budiman dan Cahya (2015) yang menggunakan media Abu Sekam Padi dengan ketebalan $15 \mathrm{~cm}$ dapat menunurnkan kandungan zat kapur sebesar 67,78\%.

Selain itu banyak penelitian lain yang telah berhasil menurukan senyawa kimia dengan menggunakan media abu sekam padi dan arang aktif seperti penelitian yang dilakukan oleh Budiman dan Amirsan (2015) yang menunjukkan bahwa arang aktif lebih efektif dibandingkan abu sekam padi dalam menurunkan kandungan BOD dan COD limbah cair Industri Tahu dengan penurunan kandungan masing-masing 39,2 $\mathrm{mg} / \mathrm{L}$ dan $78,9 \mathrm{mg} / \mathrm{L}$.

Perbandingan Efektifitas Kulit Pisang Kepok (Musa acuminate) dalam penurunan $\mathrm{Fe}$ dan $\mathrm{CaCO}_{3}$.

Kandungan $\mathrm{Fe}$ dan $\mathrm{CaCO}_{3}$ setelah perlakuan mendapatkan hasil yang bertolak belakang. Penurunan kandungan Fe lebih signifikan dibandingkan kandungan $\mathrm{CaCO}_{3}$ yang mengalami peningkatan. Adanya perbedaan nilai pengamatan pada $\mathrm{Fe}$ dan $\mathrm{CaCO}_{3}$ disebabkan gugus karboksilat dianggap sebagai asam dan memiliki afinitas yang lebih tinggi untuk basa menengah atau kuat. Ion Fe merupakan basa menengah sedangkan $\mathrm{CaCO}_{3}$ dianggap sebagai basa lemah karena tingginya polarisabilitas lebih besar dari radius ion dan meyebabkan penurunan lebih rendah.

Limbah kulit pisang kepok dapat menyerap ion logam Fe lebih baik dibandingkan menyerap $\mathrm{CaCO}_{3}$. Hal ini diakibatkan karena polaritas ion logam Fe yang lebih besar jika dibandingkan dengan $\mathrm{CaCO}_{3}$ sehingga ion logam ini akan lebih mudah berikatan dengan adsorben yang bersifat polar (Apriliani, 2010). Berdasarkan tabel periodik unsur Fe juga memiliki keeloktronegatifan yang lebih besar dibandingkan $\mathrm{CaCO}_{3}$ karena itulah diperoleh hasil bahwa penyerapan logam Fe lebih tinggi dari $\mathrm{CaCO}_{3}$.

Pada penelitian ini limbah kulit pisang kepok lebih efektif untuk menurunkan kandungan zat Fe karena Fe dapat membentuk kompleks yang stabil dengan zat organik yang larut dalam air, dimana secara kimia $\mathrm{Fe}$ merupakan logam yang cukup aktif, hal ini karena $\mathrm{Fe}$ dapat bersenyawa dengan unsur lain seperti fosfor. Sedangkan kandungan zat kapur tidak efektif karena $\mathrm{CaCO}_{3}$ di alam jarang sekali berada dalam keadaan unsur, umumnya berada dalam keadaan senyawa dengan berbagai macam valensi (Widowati, 2008).

Hewett (2011), menyebutkan bahwa kulit pisang kepok (Musa acuminate) didalamnya mengandung beberapa komponen biokimia antara lain selulosa, hemiselulosa, pigmen klorofil dan zat pektin yang mengandung asam galacturonic, arabinosa, galaktosa dan rhamnosa. Asam galacturonic dapat mengikat ion logam berat, asam ini dapat mengikat logam yang ada di air.

Berdasarkan penelitian yang dilakukan oleh Jusmanizah (2011), menunjukkan bahwa karbon aktif kulit singkong dengan kadar 2 gr untuk setiap $500 \mathrm{ml}$ air sumur dapat menurunkan tingkat kadar Fe dan Mn. Kadar Fe yang sebelumnya $2,33 \mathrm{mg} / \mathrm{L}$ turun menjadi $0,08 \mathrm{mg} / \mathrm{L}$, sedangkan kadar Mn sebelum pengolahan yaitu $2,59 \mathrm{mg} / \mathrm{L}$ turun menjadi $0,81 \mathrm{mg} / \mathrm{L}$.

\section{KESIMPULAN}

Kesimpulan dari hasil penelitian ini antara lain:

1. Limbah kulit pisang Kepok (Musa acuminate) efektif dalam menurunkan kandungan zat besi ( $\mathrm{Fe})$.

2. Limbah kulit pisang Kepok (Musa acuminate) efektif dalam menurunkan kandungan zat besi $(\mathrm{Fe})$

\section{DAFTAR PUSTAKA}

Adinata MR. 2013. Pemanfaatan Limbah Kulit Pisang Sebagai Karbon Aktif, Skripsi: Pembangunan Nasional Veteran Jawa Timur, Surabaya. 
Budiman dan Amirsan. 2015. Efektivitas Abu Sekam Padi dan Arang Aktif Dalam Menurunkan Kadar BOD dan COD pada Air Limbah Cair Industri Tahu Super Afifah Kota Palu. Jurnal Healthy Tadulako. Vol. 1 No. 2

Budiman dan Cahya. 2015. Efektivitas Abu Sekam Padi sebagai Biofilter Zat Kapur (CaC03) pada Air Sumur Gali di Jalan Domba Kelurahan Talise. Jurnal Higine, Vol 1 No 1.

Castro, Laercio caetano, Guilherme ferreira, Pedro, Margarida, Luiz, Marco antonio and Gustavo. 2011. Banana Peel Applied to the Solid Phase Extraction of Copper and Lead from River Water: Preconcentration of Metal Ions with a Fruits Waste, Industrial and Engineering Chemistry Research, 50: 3446-3451.

Chandra B. 2012. Pengantar Kesehatan Lingkungan, Penerbit Buku Kedokteran EGC, Jakarta.

Endra. 2013. Efektifitas Kulit Pisang Kepok Terhadap Logam Berat, Skripsi Institut Pertanian Bogor.

Jusmanizah. 2011. Efektivitas Karbon Aktif Kulit Singkong Dalam Menurunkan Kadar Besi (Fe) Dan Mangan (Mn) Air Sumur Gali Di Desa Amplas Kecamatan Percut Sei Tuan Kabupaten Deli Serdang Tahun 2011, Skripsi Fakultas Kesehatan Masyarakat Universitas Sumatera Utara, Medan.

Kodoatie, Robert J, dan Roestam Sjarief. 2010. Pengelolaan Sumber Daya Air Terpadu Edisi Revisi, Penerbit Andi,Yogyakarta.

Lubis. 2012. Pengaruh Penambahan Tepung Kulit Pisang Raja (Musa Paradisiaca) Terhadap Daya Terima Kue Donat, Skripsi Universitas Sumatera Utara.

Mashur. 2011. Manfaat Kulit Pisang, Lembaga Ilmu Pengetahuan Indonesia LIPI.

Mirwan A dan Hesti W. 2011. Penurunan Ion Fe Dan Mn Air Tanah Kota Banjarbaru Menggunakan Tanah Lempung Gambut Sebagai Adsorben. Info teknik volume 12, No. 1.

Nirmala, Maria VA dan Suherman. 2015. Adsorpsi Ion Tembaga (CU) dan ion besi (Fe) dengan Menggunakan Arang Hayati (Biocharcoal) Kulit Pisang Raja (Musa sapientum). Jurnal Akademika
Kimia, Volume 4, No. 4. Pendidikan Kimia Universitas Tadulako Palu

Notoatmodjo S. 2010. Metodologi Penelitian Kesehatan, Rineka Cipta, Jakarta.

Noura. 2016. Efektivitas Arang Batok Kelapa Untuk Menurunkan Kadar Zat Besi (Fe) Pada Air Sumur Gali Di Desa Samalili Kecamatan Sojol Kabupaten Donggala. Skripsi, Fakultas Kesehatan Masyarakat Universitas Muhammadiyah Palu.

Parulian A. 2009. Monitoring dan Analisis Kadar Aluminium (Al) dan Besi (Fe) Pada Pengolahan Air Minum PDAM Tirtanadi Sunggal. Skripsi Pascasarjana Universitas Sumatera Utara.

Santoso BI, Hardinsyah, Siregar P dan Pardede. 2011. Air Bagi Kesehatan. Centra Communications, Jakarta.

Setiyono A, 2014, Studi Kadar Mangan (Mn) Pada Air Sumur Gali Di Desa Karangnunggal Kecamatan Karangnunggal Kabupaten Tasikmalaya, Jurnal Kesehatan Komunitas Indonesia Vol, 10 No. 1

Qurrata. G. 2013. Penurunan kandungan zat kapur dalam air tanah dengan menggunakan media zeolit alam dan karbon aktif menjadi air bersih. Jurnal Teknik Pomist. Vol. 2, No. 2. 2013 hal 15 


\section{LAMPIRAN}

Tabel 1. Hasil Pemeriksaan Zat Besi (Fe) sebelum dan sesudah diberi Penambahan Kulit Pisang dengan Kadar 20 gr

\begin{tabular}{ccccccc}
\hline No & Perlakuan & $\begin{array}{c}\text { Kontrol } \\
\text { (mg/L) }\end{array}$ & I & II & III & $\begin{array}{c}\text { Ulangan (mg/L) } \\
\text { rata } \\
\text { (mg/L) }\end{array}$ \\
\hline 1 & 5 Menit & 0,05 & 0,013 & 0,02 & 0,017 & 0,0167 \\
2 & 10 Menit & 0,05 & 0,017 & 0,012 & 0,015 & 0,0147 \\
3 & 15 Menit & 0,05 & 0,02 & 0,011 & 0,015 & 0,0153 \\
\hline
\end{tabular}

Sumber: Data Primer, 2018

Tabel 2. Hasil Pemeriksaan Zat Kapur (CaCO3) sebelum dan sesudah diberi Penambahan Kulit Pisang dengan Kadar 20 gr

\begin{tabular}{ccccccc}
\hline No & Perlakuan & $\begin{array}{c}\text { Kontrol } \\
\text { (mg/L) }\end{array}$ & \multicolumn{3}{c}{ Ulangan (mg/L) } & Rata- \\
\hline 1 & 5 Menit & 605,13 & 717,89 & 644,29 & 740,04 & 700,0 \\
rata \\
(mg/L)
\end{tabular}

Sumber: Data Primer, 2018 